I Pontifícia Universidade Católica de São Paulo (PUC-SP),

São Paulo, SP, Brasil

mthibesster@gmail.com

II Universidade Federal do ABC (UFABC), São Bernardo do Campo, SP, Brasil

menezesmarilda@gmail.com

III Universidade Federal do ABC (UFABC), São Bernardo

do Campo, SP, Brasil

jaimesjr.22@gmail.com

Mariana Z. Thibes'

Marilda Aparecida Menezes"

Jaime Santos Júnior ${ }^{\prime \prime}$

\title{
NARRATIVAS ASSIMÉTRICAS: GÊNERO, FAMÍLIA E TRABALHO NO ABC PAULISTA
}

\section{LUGAR DAS FALAS}

Este artigo reúne resultados parciais de uma pesquisa sobre trajetórias de homens e mulheres que migraram do Nordeste para a região do ABC Paulista entre as décadas de I960 e i970. Alguns já retornaram às suas regiões de origem, outros permanecem vivendo em São Paulo. A pesquisa teve início em meados da década de I980, quando foi entrevistado um grupo de 30 famílias residentes em favelas e bairros dos municípios de Santo André, São Bernardo do Campo e São Caetano do Sul e procedentes dos municípios de Bonito de Santa Fé, Monte Horebe e São José de Piranhas, microrregião do sertão de Cajazeiras, no estado da Paraíba (Menezes, I985, 2002). Em 2013, houve a possibilidade de retomar o contato com alguns entrevistados, dando início a uma nova pesquisa, mais de 30 anos depois da realização do primeiro contato. Com efeito, novas entrevistas foram feitas com esses e outros migrantes que permaneceram na região do $A B C$ ou que retornaram aos seus municípios na Paraíba, procurando compreender, por meio de suas memórias, as experiências de trabalho, os arranjos familiares e as formas de sociabilidade que dão contorno a suas histórias de vida. Algumas entrevistas foram realizadas com o casal, outras com os cônjuges em separado. Em sua maioria, trata-se de homens e mulheres que foram socializados sob a égide de uma ética do trabalho, muito comum no meio rural, que os motivou a migrar para trabalhar e "fazer a vida" em terras paulistas. As trajetórias ocupacionais registram passagens pelas indústrias metal-mecânicas 
e automotivas da região do $A B C$ Paulista, no caso dos homens, e do trabalho majoritariamente doméstico não remunerado, no caso das mulheres migrantes. O simbolismo das falas desses sujeitos sociais está ancorado na experiência do tempo histórico e nos permite intuir o quadro social mais amplo no qual estão inseridas.

Ao contrapor as histórias de homens e de mulheres nos casos analisados, eis que nos deparamos com uma questão intrigante: as narrativas não se assemelhavam. A diferença de gênero que pauta esses discursos chama-nos a atenção para um aspecto já notado por outras autoras em narrativas femininas (Hirata e Humphrey, I992; Hirata, 2002; Biderman e Guimarães, 2004), isto é, o fio que conduz o discurso dessas mulheres é dado pelos eventos relativos à vida privada: os dramas e sofrimentos familiares, as doenças e as relações amorosas entre os membros da família. Eventos que se desenrolam no palco da vida doméstica e cotidiana e que, aparentemente, pouco se relacionam aos acontecimentos do mundo público. A fala dos homens, por outro lado, é estruturada, quase sempre, por eventos que têm lugar no mundo do trabalho. Suas histórias de vida são tecidas a partir das memórias de suas atividades na fábrica, suas alegrias e vicissitudes, e seu papel fundamental de provedor da família. Assim, ao proceder a análise das narrativas, chamou-nos a atenção esse aspecto assimétrico, que refletiria a forma como as relações familiares e de gênero são estruturadas no universo pesquisado. Desse modo, embora não estivesse contida nos objetivos iniciais da pesquisa, a noção de gênero nos apareceu como fundamental para a compreensão da assimetria que se revelava nos relatos colhidos.

Em primeiro lugar, essa diferença no "trabalho sexuado da memória" (Pisciteli, I993) poderia ser vista como um mero reflexo da organização das atividades nessas famílias, que seguiria o "modelo tradicional" (Hirata, 20 I I), em que o homem é o provedor, e a mulher cuida da casa e dos filhos. Embora essa inferência esteja correta, considerá-la o limite da análise pode obscurecer aspectos importantes da questão. Ainda que seja prematuro o alcance das nossas conclusões, entender como funcionam esses arranjos ditos "tradicionais" a partir das trajetórias de vida de mulheres e homens das classes trabalhadoras pode lançar luz sobre o modo como essas famílias equacionam decisões e elaboram projetos de vida em face do contexto em que vivem e das transformações que são obrigadas a enfrentar. É importante ressaltar que a questão da migração nordestina e da cultura operária aparece na literatura, majoritariamente, como vinculada às trajetórias dos operários do sexo masculino, pouco se atendo às relações de gênero observadas nesse contexto. Assim, acreditamos que seja possível avançar na discussão ao vincular essas questões no modo como definem o universo social e a experiência dessas famílias.

As trajetórias e as histórias de vida, como recurso metodológico, ganham destaque nessa empreitada, já que oferecem uma forma privilegiada de apro- 
ximação das experiências vividas pelos sujeitos e dos sentidos a elas atribuídos, sem abrir mão da integração das percepções individuais e sociais ancoradas no tempo (Cabanes, 20I4). A mobilização dessas categorias carrega um potencial analítico promissor para flagrar nuanças que o efeito do tempo e, com ele, mudanças no quadro social mais amplo deixam entrever. Enquanto perspectiva metodológica, trazem a pretensão de estabelecer um corte longitudinal em que se analisa como um conjunto de variáveis sofre alterações ao longo do tempo, por fatores diversos. Enquanto recurso heurístico, trajetórias e histórias de vida não nos falam apenas de percursos vistos na perspectiva individual ou de grupos, mas, sobretudo, permitem um diálogo mais amplo com as estruturas que atuam como palco para as ações humanas, sendo elas próprias arranjos instáveis. Dessa forma, o trabalho com essas histórias pode revelar aspectos que muitas vezes ficam sombreados quando se olha para essas questões somente a partir de dados mais gerais, tais como taxas de ocupação da mão de obra, diferenças salariais, inserções ocupacionais, entre outros, que são usualmente mobilizados nas discussões sobre família.

Ora, ainda que a diferença percebida nos relatos dos migrantes não fosse contraintuitiva, visto que o tema da divisão sexual do trabalho não é novo, fato é que as nuanças e especificidades presentes nessas narrativas de gênero fazem-nos supor que a equação não se resume a uma divisão de tarefas entre papéis sociais. Em face disso, procuramos refletir sobre a constituição dessa diferença a partir do modo como representações identitárias de homens e mulheres são manipuladas nesses relatos. Ao proceder dessa forma, pudemos perceber que, a despeito do modo diferente de narrar, de lembrar e de estruturar as identidades, os discursos são partes de um único projeto: a família. Esse é o pilar que estrutura a formação das identidades de homens e mulheres e lhes confere um sentido maior para seus esforços, dentro e fora de casa.

Essa não é uma ideia nova. O tema das estratégias de sobrevivência familiar dos trabalhadores, a divisão sexual do trabalho e os papéis a ela associados, os hábitos de consumo e lazer, apenas para citar os mais palpitantes, já foram objeto de acalorados debates e, certamente, permeiam o problema que nos propomos a enfrentar. Telles (I992), por exemplo, em seu trabalho junto a famílias com baixa renda, já havia sugerido que o discurso em torno da família produzido pelos sujeitos pode indicar uma medida da dignidade, para exorcizar o medo do desarranjo. Essa é também a pista que estamos seguindo.

Para tanto, nos pareceu adequado fundamentar a interpretação da relação de gênero observada nos relatos a partir da noção de "estratégias familiares". Embora a expressão possa remeter à concepção de um sujeito racional que define estratégias para maximizar seu bem-estar, a noção é aqui empregada com sentido bastante diverso. Estamos distante das abordagens que olham para as estratégias familiares a partir de sua dimensão econômica apenas ou que explicam a divisão das tarefas no lar em função de uma avaliação racional 
da rentabilidade dos recursos diferentes de homens e mulheres. Procuramos compreender a família como uma esfera situada na interface da intimidade e dos condicionantes macroestruturais representados pela sociedade e o contexto histórico. Essa esfera da vivência humana engloba uma série de práticas, valores e normas, que vão desde aqueles que se definem nas esferas mais abstratas das relações de trabalho e econômicas (Zelizer, 2009) até o mais íntimo da sexualidade e da relação com o corpo, passando pelas formações identitárias e pela definição dos papéis masculinos e femininos, assim como pelas relações entre as diferentes gerações.

As estratégias, por sua vez, são as ações de sujeitos que mobilizam seus esforços em nome de um projeto comum. Elas nem sempre coincidem com as estratégias individuais dos membros da família, como lembra Arteaga (2007 I48), e podem muitas vezes ir em direção contrária à dos desejos individuais. As estratégias englobam ações que visam à sobrevivência da família, à formação de redes de suporte e apoio, à relação entre situação de vulnerabilidade, recursos possuídos e estrutura de oportunidades, bem como às transformações que ocorrem no curso de vida e que tornam as estratégias dinâmicas. As principais formas de abordagem dessa noção em contexto latino-americano consideram e dão prevalência a um desses fatores, como sintetiza Arteaga (2007). Em nosso caso, procuramos estar atentos a todos eles, ainda que, a depender da questão discutida, um ou outro possa prevalecer.

\section{RELATOS MASCULINOS: A CENTRALIDADE DO TRABALHO NA DEFINIÇÃO DAS IDENTIDADES}

É preciso considerar, primeiramente, que os contadores das histórias aqui abordadas são sujeitos cuja origem é o mundo rural nordestino, que nasceram nas décadas de I940 a I960 e migraram para a região do ABC Paulista nas décadas de I960 e I970, portanto, no período de sua juventude. Isso significa dizer que eles trazem consigo os valores que marcam sua experiência individual, bem como o contexto histórico do período em questão: o Nordeste rural dos anos I 940 a I970. Assim, emerge com traços fortes no discurso dos homens o ideal de masculinidade do macho viril e disposto ao trabalho pesado.

O senhor Graciliano, 79 anos, que veio para São Caetano do Sul em I949, conta-nos a respeito de um conflito que teve com o chefe na época em que trabalhou em uma fábrica de cerâmica da cidade. Nos bailes que frequentava na região, ele tinha o costume de dançar com a filha do chefe, que logo passou a ouvir comentários como: "O senhor tá arrumando um genro baiano?" Comentário que soava como óbvia referência pejorativa à origem nordestina de Graciliano. Após a circulação dos boatos, Graciliano relata que começou a ser perseguido e constantemente designado para realizar tarefas "ruins" na fábrica. Certo dia, ele derrubou um carrinho carregado de tijolos e recebeu a ordem de pagar pelo material. Indignado, aceitou pagar com a condição de ficar com o 
material danificado. Sua requisição, além de negada, foi interpretada como insubordinação, servindo de mote para ser demitido por justa causa. Revoltado e sentindo-se injustiçado, ele traz a agressividade à tona como uma forma de se defender da injustiça de que se sente vítima:

Eu falei: "eu vou receber os direitos..." "Como é que você vai receber o direito?" "Eu vou. Se eu não receber aqui, eu recebo na cabeça dele". Eu falei: "eu vou matar ele na casa dele..." O gerente-geral falou: "olha, você tem coragem de fazer isso?" Eu falei: "eu tenho. Tô com vinte e poucos anos, e se eu pegar dez ou vinte anos de cadeia, quando eu sair da cadeia dá tempo de casar outra vez, pode ser até que eu volte pra casar com a filha dele". "Você tá doido?" "Não tô doido não..." É isso mesmo, quer dizer que não vou ter direito? Vou num advogado, procurar um advogado, se não, se eu não receber nada né... depois eu acerto com ele, ele vai me pagar (Graciliano, 79 anos, entrevista realizada em 6/2/2013 em São Caetano do Sul, SP).

Graciliano encontra por acaso um amigo seu na rua e conta-lhe a situação. Esse amigo, também migrante da Paraíba, leva-o até um advogado, com quem possui boas relações. O advogado faz a intermediação do conflito com a fábrica, e Graciliano consegue receber seus direitos trabalhistas. Observe-se que a mobilização das redes de apoio constituídas no bairro, a partir da origem nordestina comum, é fundamental para a resolução pacífica do problema. De todo modo, embora o recurso à violência não tenha sido mobilizado de fato, sua presença no discurso mostra um modo viril de reagir ao preconceito e à perda dos direitos trabalhistas, isto é, de forma que deixasse claro para o interlocutor que o narrador enfrentou a humilhação como "homem".

A agressividade, entretanto, nem sempre é mobilizada nesse registro. Ela também aparece como um elemento importante da nova identidade urbana do migrante nordestino quando é convertida em disposição física para o trabalho. Assim, ao sublimar seus impulsos agressivos, o "cabra macho" torna-se o "homem disposto ao trabalho", "o homem que trabalha bem" e que, graças à sua virilidade, é capaz de suportar o trabalho pesado exigido nas fábricas. Essa atividade sublimatória revela-se sobremaneira fundamental, pois, por meio dela, o sujeito não somente é capaz de integrar sua masculinidade à nova vida urbana, mas também transforma esse "velho" componente de sua identidade em um dos elementos fundamentais para criar uma nova imagem de si capaz de lhe garantir legitimidade social no novo meio. É essa virilidade, incorporada na disposição ao trabalho duro, que irá fundamentar a identidade do homem provedor.

Daí, quando entrei lá dentro (da fábrica) a gente vai desenvolvendo e vai vendo sempre o nordestino: ele tem coragem de trabalhar, e era os trampos muito pesados! (Severino, 60 anos, entrevista realizada em 7/2/2014 em São Caetano do Sul, SP).

Todas as firmas que trabalhei eu sempre tive um ambiente bom porque eu vim da roça, e a pessoa que enfrenta uma roça chega aqui: "tem trampo pesado?" Tem, mas a pessoa trabalha. Porque [...] quando você fala que é nordestino, a 
visão deles é: "esse cara trabalha". Naquela época nordestino era o contrafilé na montadora, porque põem o cara e o cara 'arregaça' (Ronaldo, 75 anos, entrevista realizada em I5/6/20I 2 em São José de Piranhas, PB).

Em outro momento, Negro (2004) e Fontes (2008) já haviam destacado a maneira como esses atributos são mobilizados pelos migrantes nordestinos em seus relatos para o enfrentamento da própria trajetória de migração. Não é casual que ela seja apresentada como narrativa épica, daquele que se lança para o "meio do mundo" e que, a despeito das dificuldades, deve superar-se. Certamente as indústrias logo perceberam que poderiam se valer dessa ética do trabalho duro; essa equação, contudo, não se resume a um simples disciplinamento dos corpos. A própria identidade de "nordestino" servirá como cimento de solidariedades tecidas entre os trabalhadores com origem comum e que alimentará resistências contra os desmandos da fábrica. Além disso, é também a virilidade aplicada no trabalho que garante que esses homens suportem o trabalho pesado e todas as dificuldades para sustentar suas famílias.

Desse modo, o componente identitário dessas falas é nítido: a masculinidade nordestina do migrante é a do homem forte, disposto ao trabalho pesado, até como uma forma de afirmar sua superioridade em relação aos paulistas, que não compartilhariam da mesma força e não seriam capazes de suportar o mesmo tipo de trabalho. Para os paulistas eram reservados os trabalhos leves de "planejamento", os quais, embora hierarquicamente superiores ao trabalho pesado, aparecem nesses discursos como menos masculinos.

Nas narrativas, tanto de homens quanto de mulheres, as trajetórias de trabalho são essencialmente masculinas. Nelas, as mulheres não aparecem, e quando o fazem, é de modo desfavorável, quase como um personagem deslocado em uma história contada pelos homens sobre os homens. No trecho abaixo, ainda que o entrevistado tenha antes mencionado que o sindicato dos trabalhadores das indústrias de produtos de limpeza era "fraco" na época em que trabalhou na fábrica da Bombril, o insucesso de uma das greves feitas na empresa é atribuído à grande presença de mulheres na fábrica, deixando entrever que essas, consideradas menos politizadas, não foram capazes de compreender a importância da greve e a ela aderir.

A greve foi um pouco difícil porque, na Bombril trabalha muita mulher, entendeu? Muita mulher, e na área do Bombril mesmo é $89 \%$ de mulher. Tirando os operadores, o resto é tudo mulher que trabalha. Então foi difícil tirar as mulheres pra parar as máquinas (Severino, 60 anos, referindo-se à greve ocorrida em I983, entrevista realizada em 7/2/2014 em São Caetano do Sul, SP).

A tentativa de excluir as mulheres dos movimentos políticos de trabalhadores nas fábricas é tão antiga quanto os próprios movimentos. Em pesquisa conduzida sobre as narrativas femininas acerca da greve de 17 de julho de I968 em Osasco, Rovai (2009: 50I9) notou que, nas falas dos homens, pouco ou nada se dizia sobre a participação feminina no evento. As mulheres eram ape- 
nas "apresentadas nos bastidores do cenário político, como colaboradoras ou espectadoras dos acontecimentos: mães, esposas, amigas e irmãs". A greve era narrada como uma "ação masculina perigosa", argumento utilizado para dispensar as operárias do movimento, "mandando-as de volta para casa, o lugar de atuação feminina" (Rovai, 2009: 5020). No entanto, como a autora salienta, embora haja essa lacuna sobre a presença feminina nos discursos masculinos, as operárias formularam seu próprio discurso sobre a experiência da greve. A especificidade de seu relato é pautada pelas relações que elas estabelecem entre as perdas físicas, políticas e emocionais, bem como pelo afastamento do caráter heroico e espetacular da greve, narrando os efeitos da greve de forma concatenada à sua própria vida particular.

A constatação desses fatos levou uma série de pesquisadores a salientar a presença da ideologia patriarcal na cultura operária, como resquícios de um mundo rural e atrasado que permanecem em meio urbano e se perpetuam ao longo das gerações (c.f Saffioti, I976). Na pesquisa feita por Luís Pereira em I958 com famílias de classe operária de Santo André, verificou-se que, de fato, acreditava-se que "as mulheres deviam viver o máximo possível dentro de casa" e limitar-se às atividades domésticas (French \& Cluff, 2000: I75), o que era acompanhado por demarcações rígidas das esferas masculinas e femininas. Entretanto, ele também constatou que, do ponto de vista das necessidades dessas famílias, "valoriza-se bastante a esposa que trabalha com remuneração para 'ajudar o marido', mas mais valorizada ainda é a situação da esposa que não precisa fazê-lo, porque ele ganha bem ou porque os filhos 'já têm ordenado'" (Pereira, I976: 3I, apud French \& Cluff, 2000: I76). Assim, o trabalho da mulher fora de casa era visto como uma exceção provocada por dificuldades econômicas ou pelo desejo da família de buscar mobilidade social para cima (Macedo, I979; Blay, I972 e Wells, I983, apud French \& Cluff, 2000: I76).

Telles (I992: 64), a partir de dados da PEA de I98I, chegou a constatação semelhante, ao observar a fragilidade dos arranjos das famílias trabalhadoras para as quais depender do trabalho das mulheres e filhos na composição da renda familiar seria "registro evidente da insegurança, da instabilidade e da precariedade inscrita em suas condições de vida". É importante levar esse fato em consideração se quisermos entender o sentido dado ao trabalho doméstico feminino não pago nessas famílias.

Além disso, outro aspecto importante dessas relações é que, para essas mulheres, a não realização do trabalho doméstico não estava posta, logo, o trabalho fora de casa só poderia ser somado àquele que seria realizado inevitavelmente na esfera doméstica. Assim, uma família em que a mulher limita suas atividades a essa esfera seria aquela que desfruta de boas condições de vida que, nesse caso, eximiriam a mulher da dupla jornada de trabalho. É preciso considerar, ademais, que no que tange à classe social examinada, constituída por famílias de operários, de origem rural, com baixa escolaridade, a oferta de trabalho 
para as mulheres consistiria em empregos pouco qualificados, de baixa remuneração. Nesse sentido, talvez seja mais compreensível que o trabalho fora de casa não lhes parecesse tão atrativo quanto seria para mulheres de classe média.

Nesse arranjo não se pode esquecer de que a identidade masculina, calcada na ideia de provedor, também gera uma série de pressões para o homem que, para manter sua condição e a respeitabilidade nela envolvida, assume para si trabalhos pesados, que não raro geram sofrimento e fazem adoecer, e dos quais não pode abrir mão em nome da sobrevivência da família.

Eu comecei a trabalhar, depois começou a aparecer problema de saúde, né? E eu procurei médico lá dentro, arrumei assistência médica lá dentro, mas não foi tão suficiente e eu procurei até assistente social, né? Então me favoreceram com o horário, eu trabalhava muito à noite e me puxaram para trabalhar só de dia.

Pesquisadora: E quais foram os primeiros problemas de saúde que o senhor teve?

Sistema nervoso muito alterado, afastado pouquinhos dias para dar uma recuperada na mente. É muito barulho e isso daí prejudicou um bocado de pessoas. Inclusive agora na idade que eu cheguei, baixou uns $20 \%$ minha audição (Ronaldo, 70 anos, entrevista realizada em 15/6/201 2 em São José de Piranhas, PB).

Observe-se como a ética do trabalho e a ética do provedor andam juntas para sustentar o projeto moral da família (Zaluar, I985; Telles, I992). Nessa intersecção entre trabalho e família compõe-se a noção de dignidade do trabalhador honesto, que faz frente às adversidades e se compromete para dar uma vida digna à sua família, saindo de sua terra de origem para buscar em um lugar distante e estranho concretizar o desejo da vida melhor. Esse homem tem pouca ou nenhuma margem para falhar, porque dele depende diretamente a sobrevivência da mulher e dos filhos; e, em nome desse projeto, precisa suportar os trabalhos mais difíceis. São muito comuns nos relatos as menções às doenças físicas e psíquicas ocasionadas pelo trabalho, embora poucos de fato realizem essa conexão de modo consciente e explícito. Junto às narrativas de sofrimento no trabalho aparecem referências frequentemente elogiosas às fábricas em que estiveram empregados. O trabalho que os fez adoecer é o mesmo que lhes garantiu realizar o projeto de vida, motivo por que devem conviver com esse conflito e com a ambiguidade de percepções.

Com efeito, encontramos nos relatos femininos, uma abundância de referências ao outro sexo em tonalidade elogiosa e heroica. Os relatos masculinos, por sua vez, parecem ser mais pobres nas referências ao sexo oposto. São frequentes na literatura sobre o tema exemplos que tratam da invisibilidade do feminino na fala masculina. Em nossos relatos, entretanto, observamos um fato peculiar: as mulheres aparecem nos relatos masculinos e neles desempenham papel fundamental, porém, não em todos os momentos. A narrativa masculina, quando transita de um tema a outro, modifica o modo de se referir à mulher. Se nas histórias de trabalho, as mulheres são invisíveis ou colocadas em posição 
inferior em relação aos homens, elas aparecem de modo heroico e reverenciado pelos homens quando se trata de seu papel de ajudar na reprodução familiar. $\mathrm{Na}$ fala que segue, ambos se referem ao período inicial de sua chegada em São Caetano do Sul, momento em que as redes de apoio de parentesco e amizade ofereciam suporte material e afetivo aos migrantes. Nesse contexto, a presença das mulheres parece fundamental como provedoras desse suporte:

Tinha a Maria que parecia uma mãe pra nós, quando a gente chegou aqui, a nossa família. Faltava gás na nossa casa e ela tirava o botijão dela pra nos dar (Dantas, 72 anos, entrevista realizada em II/7/2013, em São Caetano do Sul, SP).

E eu trabalhei em uma firma e tinha uma assistente social muito importante e ela me ajudava bastante (Vaz, 74 anos de idade, entrevista realizada em 20/3/20I4, em São Paulo, SP).

Isso mostra que as mulheres não são invisíveis nos relatos masculinos - conquanto seja interessante observar que elas aparecem como "protetoras", "cuidadoras", "salvadoras", como alguns autores propuseram -, mas que sua presença ou ausência e o modo de a elas se referir, como heroínas, vilãs, protagonistas ou coadjuvantes, varia conforme muda o tema dos relatos. Assim, os homens, quando falam sobre suas vidas privadas - a vida familiar, relações amorosas - imediatamente lembram-se das mulheres: esposas, filhas, tias, mães, vizinhas, parentes. Ao adentrar o tema do trabalho, entretanto, é imediata a supressão do feminino em seus discursos. Em seu lugar, aparecem as relações com os outros homens: os colegas de trabalho, os chefes, os parentes do sexo masculino. Mesmo no caso da assistente social citada na entrevista, note-se que, embora pertencendo ao ambiente de trabalho, ela tem sua importância reconhecida quando o entrevistado se refere à sobrevivência da família.

No caso de entrevistas feitas com o casal simultaneamente - como é o caso de Joana, 59 anos, e Dantas, 72 anos, ele tendo migrado para São Caetano do Sul em I962, e ela em I982 -, é possível notar determinadas transições nas falas que evidenciam o domínio a que cada um deve remeter-se ao contar a história. Quando a pergunta se refere a "emprego", o homem é quem deve as sumir o relato. No trecho abaixo, quando perguntamos sobre as ocupações do entrevistado, a mulher tenta assumir a interlocução, mas rapidamente é interrompida e convocada a silenciar. Ela, entretanto, continua a falar e retorna ao tema das dificuldades de sobrevivência da família, em vez de deixar o marido nos contar sobre a sua experiência de trabalho.

Pesquisadora: Então, eu queria que o senhor contasse pra mim, como o senhor quisesse contar, desde a chegada, os empregos, como é que foi?

Joana: Foi difícil.

Dantas: Deixa eu contar a história pra ela. Mas deixa eu contar essa história pra ela! 
Joana: A gente comprava aquelas bengalas, e eu tinha os cinco [filhos], né? Aí eu media pra cada um um pedacinho de pão, assim, pra tirar um pedacinho da bengalinha pra dar a bengala pra todo mundo. Aí tinha um que dizia: "Ah, o meu pedacinho ficou menor". Eu media os pedacinhos pra eles (entrevista realizada em II/7/2013, em São Caetano do Sul, SP).

Essas transições nas falas revelam que tanto a memória feminina das dificuldades da vida quanto a memória masculina das trajetórias de trabalho acabam se equacionando como notas diferentes de uma mesma melodia, isto é, a empreitada conjunta de sobrevivência da família. No caso das famílias operárias com as quais trabalhamos, está claro que a estratégia definida se baseou no modelo de chefe provedor e da mulher que toma conta da vida doméstica. Esse foi um arranjo predominante para as primeiras gerações de migrantes, mas que começou a mudar nas gerações subsequentes, como demonstram os relatos aqui apresentados. De todo modo, a referência à família como um código valorativo que guia as ações, define papéis e ordena trajetórias nos faz lembrar, sobretudo, que ela permanece sendo uma das mais importantes vias de ordenamento das relações sociais. A família como ordem moral que vincula os domínios público e privado é a esfera que permite visualizar propriamente os vínculos entre o mundo do trabalho, as doenças, os sofrimentos, as dificuldades financeiras, a criação dos filhos e a vida cotidiana. Em uma sentença, não se trata de assuntos diferentes. Assim, as transformações que vislumbramos nas identidades de gênero, de uma geração a outra, também ficam mais nítidas quando observadas a partir das relações que se tecem no âmbito da família e de sua importância como ordenamento moral.

Interessante notar, nesse sentido, como Severino (55 anos) recorda-se de eventos importantes do ciclo da vida, como o nascimento de suas filhas, a partir de uma associação com o trabalho exercido na época: o pedido de demissão da fábrica em que trabalhava, no caso da primeira filha, e a mudança de trabalho - da fábrica para a aquisição de um bar - no caso da segunda.

Esse negócio de [turno] 7 por I, nasceu minha filha, sabe? Aí tinha um aniversário, tinha um casamento, ela [a esposa] ia, e eu não ia. Aí eu falei: "não tá dando certo!" Falei pra ela: "eu vou sair!” Aí houve um problema de greve lá, eu aproveitei e saí. Aí depois de dois anos e meio eu comprei esse bar na [avenida] Sacadura Cabral e lá fui trabalhando eu e minha esposa. Depois nasceu a outra menina e eu tava no bar ainda (Severino, 60 anos, entrevista realizada em 7/2/2014 em São Caetano do Sul, SP).

Ainda que quase todos os homens entrevistados na pesquisa estivessem aposentados na ocasião da entrevista, o trabalho nas fábricas ou em outros lugares permanece como aspecto estruturante e definidor da identidade, o que se reflete no modo de contar a própria história. É possível notar, entretanto, como esses mesmos homens, quando falam de trabalho, também estão a falar da família. Assim, a reprodução familiar, para a qual as mulheres contribuem de modo 
fundamental com suas atividades na esfera privada, está longe de ser um tema menor ou menos caro a esses homens. Ao contrário, ela constitui a grande razão pela qual dão sentido ao próprio esforço no mundo do trabalho fora de casa.

Trinta e poucos anos de casado e eu não desfiz de um tostão a não ser pra família. [...] Tudo o que eu fiz depois que casei foi pra dentro de casa, tudo. Ela é testemunha disso aí (Ronaldo, 70 anos, entrevista realizada em I5/6/2013, em São José de Piranhas, PB).

Graças a Deus criei e construí família, tenho minha família, tenho amigos e onde cheguei sou respeitado (Dimas, 6I anos, entrevista realizada em 28/3/20I3, em São José de Piranhas, $\mathrm{PB}$ ).

A lógica presente nessas falas deixa entrever uma hierarquia de valores em que a família é considerada o grande objetivo para o qual convergem todos os esforços, tanto os masculinos quanto os femininos. A família é, portanto, a base para uma ordem moral que justifica os esforços, garante a dignidade e estrutura a divisão dos papéis entre homens e mulheres.

Na história de Alcides e Antônia, a doença da mulher motiva o retorno do casal ao Nordeste após terem vivido 40 anos no estado de São Paulo. Ao chegar nesse assunto, Alcides concede a autoridade do relato à mulher, já que eventos dessa ordem, isto é, as doenças e os assuntos privados, dizem respeito ao domínio feminino. Ao ressaltar que "na casa quem manda é a mulher", ele manifesta claramente o modo como se dá a divisão das funções entre o casal. É só quando cada um desempenha a parte que lhe cabe que a divisão pode tornar-se, para ele, símbolo da união do casal.

Pesquisadora: Mas, assim, como é que o senhor foi decidindo, o senhor e sua esposa decidindo voltar [para o Nordeste]? Foi de repente? Como é que foi essa decisão?

Essa decisão foi em 2008, ela [a esposa] tinha fibromialgia, e os médicos mandaram ela procurar um lugar quente; ela conta um pouco dessa parte a vocês; essa eu deixo pra ela, porque nós somos unidos, cada um tem sua parte. A palavra bonita é essa: Quem manda em casa é a mulher! [risos]. Se o homem trouxer um quilo de feijão e a mulher fizer, ele fica com dois quilos. Isso é um casal bem unido e vive muito. A mulher que o homem dá um quilo de feijão e ela joga metade fora, nunca se vai pra frente, né? Né assim? (Alcides, 62 anos, entrevista realizada em 27/3/2014, em São José de Piranhas, PB).

Assim, o arranjo evidenciado pelas falas não apenas reflete a estrutura da divisão tradicional do trabalho entre os sexos, mas se constitui como um arranjo que, do ponto de vista dos interlocutores, é considerado imprescindível para que a família, o bem maior a ser zelado, prospere. Nesse sentido, além da questão da natureza interdependente da unidade familiar na classe operária e seu papel para a sobrevivência material, há uma ênfase valorativa explícita na família como centro de gravidade para o qual são direcionados os esforços de homens e mulheres. Somente sua apreensão como ordem simbólica (Sarti, 2003) é capaz de captar a importância da família nesse contexto. 


\section{A SINGULARIDADE DAS FALAS FEMININAS}

As pesquisas que buscam compreender as especificidades do trabalho sexuado da memória confirmam a existência de uma associação entre a memória feminina e o domínio da família, da vida privada e doméstica (Piscitelli, I993). A fala das mulheres que escutamos é recheada por eventos relativos ao universo familiar, às doenças, aos sofrimentos e à intimidade. É preciso considerar que no momento da nossa conversa, quase todas as mulheres entrevistadas possuíam atividade restrita à esfera doméstica. Muitas nunca trabalharam fora de casa ou trabalharam por um breve período interrompido pelo casamento ou o nascimento dos filhos, ou ainda de maneira intermitente com pequenas ocupações.

Ao contrário dos homens, que procuram narrar suas histórias a partir de suas vitórias e conquistas, omitindo ou pouco se atendo aos problemas pessoais e íntimos, são esses que ganham destaque nas falas das mulheres. $\mathrm{Na}$ história de Marta, de 55 anos, por exemplo, fica evidente como os eventos que mobilizam a memória são aqueles relativos à dor e ao sofrimento experimentados ao longo da vida. O trecho abaixo é importante porque é a forma como Marta escolhe para dar início à narrativa de sua história de vida. Ela ficou órfã com apenas um ano de idade, tendo ido morar com seus tios. A narrativa tem início a partir das lembranças desse período da infância, em que ainda vivia na zona rural, período associado ao sofrimento que ela sentiu, ao problema psíquico do tio e aos cuidados que ela devia prestar a ele por conta disso.

A gente levou uma vida muito sofrida com minha tia. Meu tio tinha problema de nervo, ficava internado em João Pessoa, nós ia pros meios do mato. Ele com os filhos dele e a minha tia. Ele era irmão do meu pai, e eu fiquei muito com ele. Eu ficava muito apegada com eles. Aí eu tinha que acompanhar, porque ele não tava bem, né? E a gente entrava nos meios do mato. E ele tinha medo dos barulhos dos carros. Naquela época não tinha nem carro, mas ele tinha medo do barulho. Aí ele ia pro mato. Ele achava que era polícia que estava vindo buscar ele. Ficava trancado dentro da casinha e nós ficava junto. Eu ainda não tava casada, então ficava muito ali com meu tio. Aí logo comecei a namorar. Não sabia de nada. Casei. Com o primeiro eu casei. Aí no segundo ano de casado foi que veio nascer o Zé (Marta, 55 anos, entrevista realizada em I I/7/2013, em São Caetano do Sul, SP).

Em razão do problema psíquico do tio que o fazia ter medo do barulho dos carros, Marta e seus primos iam morar nesses lugares afastados (os "meios dos matos"). Ela, então, ajudava a tia no cuidado da casa e do tio doente. É interesse notar como a história é sintetizada nesse trecho inicial, contada a partir de suas relações com os homens - o tio, o marido e o filho. Em seguida, Marta é indagada sobre a viagem de vinda para o Sudeste, cujo relato é realizado a partir da descrição de uma cena íntima, o banho nas crianças. No cuidado dos filhos, duas figuras aparecem para ajudá-la durante a viagem: a irmã e um conhecido do sexo masculino chamado Sandoval. O destaque que esse personagem adquire na história denota a excepcionalidade de sua ajuda: o fato de um homem se envolver nesse tipo de tarefa adquire o sentido da generosidade, já que não há 
obrigação envolvida no ato. A ajuda da irmã, por sua vez, quase passa ao largo da observação, surgindo como trivial e provavelmente pressuposta por ela.

Então, esse Sandoval ajudou trazer a gente de ônibus, com os filhos viajando. Ele ajudava a trocar roupa, a gente dava banho nos tanques bem grande na viagem, nos hotel onde a gente... Nas pensão, né? A gente dava banho, eu e minha irmã dando banho e ele trocando as crianças. Amauri era menino, né? E ele dava banho e ele trocava, ajudava pra poder comer, senão não dava tempo de comer (Marta, 55 anos, entrevista realizada em II/7/2013, em São Caetano do Sul, SP).

Em entrevista realizada simultaneamente com um casal composto por uma mulher de 53 anos (Lúcia) e um homem de 60 anos (Carlos), é possível notar com clareza como a forma de narrar os mesmos acontecimentos é diferente para cada membro do casal. O relato de Lúcia revela uma face da vida privada que dificilmente apareceria na fala de Carlos, isto é, o sofrimento causado pela dependência alcoólica do marido. A bebida é mobilizada de tempos em tempos em sua fala sempre com o propósito de enfatizar à entrevistadora a dor que gerou a ela e aos filhos. A entrevista parece constituir uma oportunidade de vocalizar esse sentimento. Os pontos enfatizados na história são, além do sofrimento, a falta de dinheiro em casa, a saúde deteriorada do marido e o medo de que os filhos seguissem o exemplo do pai e se tornassem dependentes alcoólicos. No trecho abaixo, ela conta sobre o período em que decidiram voltar ao Nordeste, momento em que, segundo ela, chegaram a passar fome. Logo em seguida, o marido intervém para esclarecer que essa dificuldade foi passageira e que ele sempre foi "ganhador de dinheiro", ou seja, foi capaz de cumprir o papel de provedor. Desse modo, nota-se um conflito entre duas versões desse período de suas vidas: a da mulher, que ressalta o sofrimento e a falha do marido em conseguir um trabalho e prover o sustento da família, e a tentativa dele de preservar sua imagem de provedor, trabalhador e "ganhador de dinheiro". Do mesmo modo, a bebida, vista pela mulher como sinal de que o marido fracassava em seu papel, é narrada por ele de outra forma, associada aos momentos de diversão na fábrica.

Lúcia: aí depois a coisa começou a estreitar, aí ele reclamava porque estava comendo feijão puro e não tinha mistura. [...] Ele começou reclamando e bebendo mais e bebendo mais e assim, dizia que era porque tava passando fome e que não tinha mistura pra comer. Eu disse, a "desculpinha" é essa, aí eu dizia isso mesmo, a desculpa é essa porque lá em São Paulo trabalhava e bebia, e aqui só fazia beber. Não tinha trabalho, aí foi quando ele disse: "não, eu vou embora".

Carlos: eu quero só falar pra vocês que o meu sofrimento foi pouco, se foi uns três meses foi muito, porque sempre eu fui o ganhador de dinheiro. Já tive muito dinheiro!

Lúcia: ele ganhava, ele sabia ganhar dinheiro, mas sabia gastar também.

Carlos: eu já possuí carro novo. Hoje eu não tenho inveja de quem tem, de quem brincou, de quem comeu, porque eu sempre fui comedor. Sempre veio tudo fácil 
para minha mão, não teve nada difícil. (O casal foi entrevistado em 28/3/20I4, em São José de Piranhas, PB e em I983, em São Bernardo do Campo, e o trecho pertence à entrevista mais recente).

Já na fala de Carlos, embora a bebida não seja omitida, ela aparece em um registro lúdico, associada aos momentos de diversão na fábrica, sobretudo às sextas-feiras em que os operários levavam linguiça e cachaça para festejar após o término do expediente. Em contraposição, Lúcia menciona que a bebida foi um dos fatores que motivaram a volta do casal ao Nordeste, uma vez que, estando o marido desempregado e com poucos recursos, não viram outra saída senão voltar a morar na casa dos pais dela. Carlos então reage para enfatizar o oposto, dizendo à entrevistadora que a situação de miséria foi de curta duração e que, ao contrário do que a esposa narrou, ele foi capaz de ganhar dinheiro. A tonalidade do relato passa, então, abruptamente, de uma situação de penúria a uma situação de abastança e vitória, e a vida sofrida narrada por Lúcia transmuta-se em uma vida fácil e cheia de prazeres na voz de seu marido. Estando os dois narradores a falar sobre sua vida em conjunto e se reportando aos mesmos acontecimentos, é digno de nota o fato de a narrativa adquirir tonalidades tão flagrantemente opostas. Enquanto a mulher narra a história do casal com a ênfase nos sofrimentos e dificuldades, o homem parece se sentir no dever de ressaltar que, apesar das intempéries vividas, o que prevalece é a vitória. Mesmo a relação com a bebida, ao fim do relato, surge como um caso de superação, como uma forma de inseri-la, também, no rol das demais conquistas de sua vida.

Fica nítido como Carlos, assim como os outros personagens masculinos dessas histórias, se veem no dever de transmitir uma imagem de vitoriosos. É essencial para a manutenção de sua identidade que ele tenha sido capaz de trabalhar, ganhar dinheiro, sustentar a família, e que tenha tido sucesso na empreitada da migração. Quando esse papel é ameaçado pelo desemprego, pelo alcoolismo ou outras dificuldades, é apenas a mulher quem o menciona, já que, para o homem, esses dados seriam contraditórios à imagem heroica que desejam transmitir de si próprios. É provável que a própria migração, vivenciada com tonalidades épicas pelos homens, reforce essa representação masculina.

A despeito do fato de que as mulheres não omitem os sofrimentos e as dificuldades da vida como fazem os homens, isso não significa, porém, que não compartilhem da referência ao heroísmo masculino. O que ocorre é que nas histórias por elas contadas a dualidade é constante: o homem herói também é o homem que fraqueja, assim como o bom marido também as faz sofrer. Ao contrário das histórias masculinas em que só heroísmo aparece, nas histórias das mulheres essas tensões são frequentes.

No relato de Filomena, 60 anos, é possível notar claramente a presença dessa dualidade. Embora ela seja enfática para relatar a dor que os homens lhe infligiram, há a constatação de que eles também eram pessoas "muito boas". 
Primeiro, ela se refere ao pai, que era "ignorante" e "rude" e batia nos irmãos, "uma pessoa ruim". Depois, ao marido, que era "mulherengo", "frio" e "distante", e que também ganhava pouco. Uma narrativa, em princípio, oposta ao heroísmo dos homens. Entretanto, embora no caso do pai, a narrativa mantenha-se constante, no caso do marido, há algumas nuanças que invertem a prosa: o marido, apesar dos defeitos apontados e do sofrimento que lhe causou, também é retratado como "uma pessoa boa" e um "pai maravilhoso".

Ele lavava a louça, ele fazia comida, um pai maravilhoso. Então ela [a filha do casal] sofreu muito quando ele faleceu.

$\mathrm{Na}$ época em que a Luana tinha três anos ele aprontou muito, mas era uma pessoa boa. Eu fiquei 33 anos casada e nunca vi este homem nervoso. Eu sempre fui assim, as meninas falam que não sabe como ele me aguentava (Filomena foi entrevistada em I2/3/2014 e em I983, em São Caetano do Sul, SP as duas vezes, e o trecho pertence à entrevista mais recente).

Observem-se duas coisas nesse relato, a primeira, diz respeito à cisão das formas de se referir ao marido. Quando ele é lembrado em seu papel de pai, torna-se "maravilhoso", mas, quando Filomena lembra dele na relação conjugal, a memória adquire tonalidades negativas. Isso sugere que o papel de pai e sua importância na família se sobrepõem à própria percepção individual de Filomena sobre seu marido. O segundo aspecto diz respeito a como, após uma narrativa em que o marido lhe causa muita dor, ela termina por retratar-se como pessoa exigente e de difícil convívio, enquanto ele, antes "mulherengo" e "frio", é mencionado como uma pessoa "calma" e "boa". E, então, já não é ela quem sofre pelo marido, mas o marido que deve ter sofrido por conta dela.

Há ainda outro aspecto que nos chama a atenção em seu relato. Em algumas passagens, ao lembrar de momentos difíceis de sua vida, Filomena mostra claramente como seu sofrimento esteve ligado ao fato de o marido não se encaixar a contento no papel de provedor, em virtude de seus baixos salários, de sua instabilidade nos empregos e de nunca ter sido capaz de comprar uma casa, tendo a família sempre morado de aluguel. Essa condição exigiu que as filhas começassem a trabalhar cedo para ajudar nas despesas da casa. Boa parte do sofrimento relatado por Filomena parece advir dessa não correspondência do marido tanto ao papel de provedor da família quanto ao de um bom marido na vida conjugal (era mulherengo, frio etc.). A despeito disso, quando ele falece, ela sente a perda de modo intenso, questionando sua própria posição como mulher na família e sua dependência em relação a ele.

Em virtude da instabilidade do marido nos empregos, Filomena também passou a trabalhar "para ajudá-lo". Ela conta que exerceu por dois anos a função de diarista, mas ressalta que o fez para auxiliar o marido e não por vontade própria. Note-se que o trecho de sua fala em que menciona essa passagem de sua vida evidencia que, a seu ver, quem deve exercer a função de ganhar o sustento da família é o homem, e apenas por necessidade é que a mulher intervém com ajuda. 
Ele trabalhava na Volkswagen, depois ele saiu, e depois a Bárbara nasceu. Eu sempre tive uma vida muito sofrida porque ele ganhava pouco, não tinha estabilidade no emprego e eu paguei aluguel por 33 anos. Eu morei em cortiço. Eu não tenho vergonha de falar isso. Teve uma casa que eu morei três meses e quase que eu fui despejada porque o meu marido ganhava pouco e as crianças eram pequenas, depois que elas cresceram e começaram a trabalhar e começaram a ajudar... Depois ele entrou na prefeitura, mas eu fui trabalhar para ajudar ele; durante dois anos eu trabalhei como diarista pra ajudar ele, porque ele ganhava pouco, mas fazia tudo: ele lavava a louça, ele fazia comida, um pai maravilhoso (Filomena, 60 anos, entrevista realizada em I2/3/20I4 em São Caetano do Sul, SP).

A dubiedade do trecho é evidente e denota o conflito que Filomena viveu em sua relação conjugal e familiar. Ao mesmo tempo em que o homem falha como provedor e como marido, ela não deixa de ressaltar suas qualidades positivas como pai e dentro de casa, ao auxiliar nas atividades domésticas. Note-se que a participação dele nessas atividades é vista como um ato de generosidade e não como dever, como a forma que ele, caracterizado como homem frio, era capaz de demonstrar carinho à mulher, e não como uma obrigação ou divisão de responsabilidades. Desse modo, assim como Filomena não se vê responsável pelo sustento da casa (apenas "ajuda o marido"), ela também não vê o marido como responsável pelas atividades domésticas (ato de carinho, de generosidade).

Em outras situações, as mulheres percebem que poderiam ter contribuído para uma vida mais confortável se exercessem ativamente um trabalho remunerado, não apenas como coadjuvantes para auxiliar financeiramente os maridos nos momentos de dificuldade. É o caso de Maria (62 anos), que tendo sido impedida de trabalhar fora de casa pelo marido, Vaz (74 anos), ressente-se de não ter direito ao benefício da aposentadoria, percebendo que as condições financeiras do casal seriam melhores se ela houvesse trabalhado fora de casa. Ela afirma, entretanto, que não se arrepende do modo como viveu, já que o marido foi capaz de sustentar a família, ainda que as dificuldades não tenham sido poucas. Essa dualidade constante nas narrativas femininas deixa transparecer como as estratégias familiares criadas são objeto de tensões e conflitos: se, por um lado, são consideradas um modo de vida digno que afasta o medo do desarranjo, por outro, criam pressões e limitações aos membros da família.

Porque não é feio uma mulher trabalhar, e ele não quis que eu trabalhasse. Se eu tivesse trabalhado, hoje eu já estaria bem adiantada para minha boa aposentadoria, né? Se fosse hoje, a partir do que eu já entendo, o que eu já aprendi aqui em São Paulo, eu não estaria sendo só dona de casa, eu estaria trabalhando. Pro dia de amanhã ser mais fácil pra gente, né? Mas graças a Deus eu não me arrependo, ele sempre foi um bom homem de casa, um bom trabalhador. Tivemos nossas filhas, me orgulho das filhas que eu tenho, fizemos tudo. As duas são formadas, graças a Deus. Tivemos nossos problemas financeiros, e porque eu moro aqui, nessa casa pequena, não significa que eu vivo na pior, eu vivo bem, graças a Deus. Eu como do que eu quero, não devo pra ninguém, vivo com a minha cabeça erguida e tem muita gente por aí, que tem casa própria, tem seus 
carros e não é feliz. [...] eu vivo feliz aqui em São Paulo, deixei minha terrinha lá, eu sinto saudade de lá, não vou embora porque nós construímos nossa família aqui, e eu não vou deixar. Aquilo que Deus me deu, que é minhas filhas, são herança de Deus, eu não vou deixar pra trás (Maria, 62 anos, entrevista junto com Vaz, 74 anos, realizada em 20/3/2014, em São Caetano do Sul, SP).

Cabe ressaltar o modo como o arranjo familiar se sobrepõe à vontade individual de Maria de trabalhar fora de casa e retornar ao Nordeste. Isso fica nítido quando ela menciona que, a despeito da vida difícil e dos problemas financeiros, foram capazes de ser bem-sucedidos como família e dar uma vida melhor às filhas, oferecendo-lhes a oportunidade de frequentar uma faculdade. Ela atribui a isso a razão de seus sacrifícios individuais e também a sua própria felicidade no presente. Desse modo, vemos como o projeto coletivo representado pela família adquire preponderância sobre os desejos individuais de seus membros, não apenas moldando-lhes as identidades, mas limitando os horizontes de expectativas de um lado e de outro oferecendo uma via segura de acesso ao mundo.

Esse sacrifício dos desejos individuais em nome desse projeto familiar estruturado da forma como descrevemos no artigo é observado em diversos relatos de mulheres colhidos em nossa pesquisa. Diana, por exemplo, de 52 anos, que migrou durante a juventude para São Paulo, relata a dificuldade que teve, durante a infância e adolescência na zona rural nordestina, para conseguir estudar. Enquanto o pai e a mãe trabalhavam na roça, ela devia permanecer em casa para desempenhar as tarefas domésticas. Apenas quando completou I4 anos é que conseguiu dar início aos estudos, nos fins de semana, em uma escola na zona urbana de Várzea Alegre, no Ceará. Concomitantemente à realização dos estudos, ela também arrumou um emprego como professora primária de uma escola da zona rural onde ficava o sítio da família. Ela conta que foi criada de modo muito rígido pela mãe, não tendo liberdade para sair de casa, e que via o casamento como uma forma de conquistar mais autonomia. Após casar-se, entretanto, teve de interromper os estudos e o trabalho como professora a fim de acompanhar seu marido na viagem para São Paulo. Como ele trabalhava em uma fábrica à noite e dormia durante o dia, ela passava o dia todo sozinha.

Aí foi que eu me senti sozinha. Aí eu disse, nossa, cadê minha liberdade? Porque eu casei para ter liberdade, cadê minha liberdade? Eu acho que foi uns dois anos nesse sofrimento (Diana, 52 anos, entrevista realizada em 20/9/2015, em São Paulo, SP).

Nesse período, já grávida da única filha, Diana passou a desempenhar, exclusivamente, o trabalho doméstico não remunerado. Em seu relato bastante emocionado, evidencia-se o sentimento ambíguo ao examinar sua história de vida: ela afirma sentir-se grata e feliz por ter criado a filha, mas também se ressente por não ter podido realizar seus desejos individuais de estudar e trabalhar fora de casa. 
Pesquisador: Você fez o magistério?

Não, eu não terminei. Aí depois quando casei, parei de estudar. Me arrependi muito.

Pesquisador: Você casou com quantos anos?

Com 20. $[\ldots]$

Pesquisador: Diana, se você tivesse que dizer, assim, de tudo o que passou, o que foi a sua vida?

Eu acho que uma frase define isso, que é, no fundo, eu consegui, eu cumpri minha missão.

Pesquisador: Olhando para trás você acha que você conseguiu tudo o que você queria conseguir?

Não. O que eu queria na minha vida era trabalhar. Eu nunca sonhei assim com essas coisas materiais porque pra mim isso não tem muita importância.

Pesquisador: Mas você acha que é tarde pra correr atrás disso tudo agora?

Acho que é, porque agora não tenho mais disposição. Antes eu queria trabalhar, ter minhas coisas, eu queria ter uma casa só minha. Queria conseguir um carro, uma casa, uma família. Mas muita coisa eu consegui, graças a Deus. Mas eu também não reclamo, dou graças a Deus por chegar onde cheguei, tenho que agradecer a Deus pelo que tenho na minha vida [bastante emocionada].

É importante notar como as duas mulheres, Maria e Diana, procuraram prover um destino diferente para suas filhas, incentivando-as a fazer uma faculdade e trabalhar fora de casa. Quando indagada sobre o que faria caso o marido de sua filha de 24 anos a impedisse de trabalhar fora de casa, Diana responde incisivamente que não permitirá que a filha reproduza sua trajetória:

Pesquisador: E o que mais você conversa com ela? Por exemplo, se o namorado dela disser para ela ficar em casa, não trabalhar.

Ela não vai ficar. Eu vou dar apoio. É tão ruim você depender das pessoas, eu digo isso por experiência própria. Tudo bem que ele não me deixou faltar nada, tudo o que eu queria ele me dava. Mas, é bom você ter as suas coisinhas, sabe?

Desse modo, é possível observar mudanças importantes no modo de criar as gerações seguintes de mulheres dessas famílias, o que reforça o aspecto geracional das estratégias familiares, mostrando como as estruturas que informam a ação podem ser arranjos instáveis. A família permanece como uma estrutura fundamental para o projeto que visa à ascensão de filhos e filhas, em que a educação vigora como pilar fundamental. No que tange especialmente às filhas, realizar esse projeto coletivo da família matriculando-se na universidade e trabalhando fora de casa significa, além da realização do projeto familiar transmitido pelos pais, o seguimento de uma trilha de maior autonomia em comparação à de suas mães, dado que outras possibilidades são abertas em suas vidas. 


\section{ALINHANDO OS FIOS}

Procuramos mostrar como o trabalho da memória, que se distingue para homens e mulheres, pode ser interpretado como tendo seus alicerces nas construções identitárias e nos papéis que esses personagens desempenham para a realização de um projeto comum e que possui importância fundamental em suas vidas: a família.

A família se torna, portanto, o pilar da estruturação de um projeto de vida que (re)define os papéis, as identidades, e, por conseguinte, as biografias. Mais do que isso, ela é vista como uma entidade moral que confere dignidade e uma posição no mundo para seus integrantes. É a partir dela que se definem os lugares de homens, mulheres e filhos como aqueles que simbolizam a esperança de um futuro melhor e que justificam os esforços empreendidos por pais e mães. Procuramos mostrar também como a migração, parte fundamental do projeto das famílias pesquisadas, oferece uma perspectiva importante nos estudos de gênero, sobretudo quando aliada a um ponto de vista geracional.

À guisa de conclusão, portanto, pode-se afirmar que o modo de vida pautado pelos arranjos que descrevemos se revela como uma forma de dar sentido à vida e estruturar os projetos familiares da geração aqui descrita. Esses arranjos, conforme nossos indícios apontam, têm um lastro geracional: é possível notar mudanças importantes no modo de vida das filhas. Entretanto, é preciso ressaltar os conflitos e as limitações que eles determinaram, ao impor pressões consistentes a homens e limitações significativas às mulheres.

Além disso, esse foi um modo de vida que se pôde firmar devido às condições materiais de existência de uma determinada geração, em que o trabalho na indústria não havia ainda sido afetado de modo tão drástico pela crise do setor. Tendo isso em vista, resta observar como as mudanças serão incorporadas pelas gerações seguintes e se esse modo de vida e essas estratégias poderão ser levados adiante ou transformados pelas imposições das mudanças históricas. Nossas observações nesse sentido são ainda incipientes, mas já permitem notar mudanças importantes nos projetos e nas trajetórias de vida das mulheres das gerações mais jovens do universo pesquisado.

Recebido em I8/7/20I7 | Revisto em 3/II/20I7 | Aprovado em 4/I I/20I7 


\section{NOTA}

I Os nomes doravante citados são fictícios a fim de preservar o anonimato das fontes.

Mariana Z. Thibes é doutora em sociologia pela Universidade de São Paulo, pós-doutora em ciências sociais pela Universidade Federal do ABC e pós-doutoranda em ciências sociais pela Pontifícia Universidade Católica de São Paulo, com financiamento da Fapesp.

Marilda Aparecida Menezes é professora visitante sênior na Universidade Federal do ABC, vinculada ao Programa de Pós-Graduação em Ciências Humanas e Sociais, e pesquisadora do CNPq.

Jaime Santos Júnior é doutor em sociologia pela Universidade de São Paulo e pós-doutorando em ciências sociais pela Universidade Federal do ABC. 


\section{REFERÊNCIAS BIBLIOGRÁFICAS}

Arteaga, Catalina A. (2007). Pobreza y estrategias familiares: debates y reflexiones. Rev Mad., I7, p. I44-I64.

Biderman, Ciro \& Guimarães, Nadya Araujo. (2004). Na antessala da discriminação: o preço dos atributos de sexo e cor no Brasil (1989-I999). Estudos Feministas, Florianópolis, I2/2, p. I77-200.

Cabanes, Robert. (20I4). Economie morale des quartiers populaires de São Paulo. Paris: L’Harmattan (Coll. Recherches Amériques latines). Fontes, Paulo. (2008). Um Nordeste em São Paulo: trabalhadores migrantes em São Miguel Paulista (1945-66). Rio de Janeiro: Ed. FGV.

French, John D. \& Cluff, Mary Lynn Pedersen. (2000). As mulheres e a mobilização operária na época de pós-guerra em São Paulo, I945I948. História Social, Campinas, 7, p. I7I-2II.

Hirata, Helena. (2010). Emprego, responsabilidades familiares e obstáculos sócio-culturais à igualdade de gênero na economia. Revista do Observatório Brasil da Igualdade de Gênero. Brasília: Secretaria Especial de Políticas para as Mulheres, p. 45-49.

Hirata, Helena. (2002). Travail et affects. Les ressorts de la servitude domestique. Travailler, Paris, 8, p. I3-26.

Hirata, Helena \& Humprhey, John. (I992). Estruturas familiares e sistema produtivo: famílias operárias na crise. Tempo Social, São Paulo, 4/I-2, p. 53-93.

Menezes, Marilda A. (2002). Redes e enredos nas trilhas dos migrantes: um estudo de famílias de camponeses-migrantes. Rio de Janeiro/João Pessoa: Relume Dumará/EDUFPB.

Menezes, Marilda A. (I985). Da Paraíba para São Paulo e de São Paulo para Paraíba: migração, família e reprodução da força de trabalho. Dissertação de Mestrado. Universidade Federal da Paraíba.

Negro, Antonio Luigi. (2004). Linhas de montagem: o industrialismo nacional-desenvolvimentista e a sindicalização dos trabalhadores. São Paulo: Boitempo.

Pereira, Luiz. (1976). A escola numa área metropolitana: crise e racionalização de uma empresa pública de serviços. São Paulo: Pioneira.

Piscitelli, Adriana. (1993). Tradição oral, memória e gênero: um comentário metodológico. Cadernos Pagu, Campinas, I, p. I49-I7I.

Rovai, Marta G. de Oliveira. (2009). Narrativas femininas sobre o heroísmo masculino: as fronteiras do gênero. IV Congresso Nacional de História, Maringá, PR, Brasil. 
Saffioti, Heleieth Iara Bongiovani. (I976). A mulher na sociedade de classes: mito e realidade. Prefácio de Antonio Candido de Mello e Souza. Petrópolis: Vozes.

Sarti, Cynthia Andersen. (2003). A família como espelho: um estudo sobre a moral dos pobres. São Paulo: Cortez.

Telles, Vera da Silva. (I992). A experiência da insegurança: trabalho e família nas classes trabalhadoras urbanas em São Paulo. Tempo Social, São Paulo, 4/I-2, p. 53-93.

Zaluar, Alba. (1985). A máquina e a revolta. As organizações populares e o significado da pobreza. São Paulo: Brasiliense. Zelizer, Viviana A. (2009). The purchase of intimacy. Princeton: Princeton University Press. 
Palavras-chave

Histórias de vida; migração; gênero; identidades; trabalho.

Keywords

Life stories; migration;

gender; identities; work.

\section{NARRATIVAS ASSIMÉTRICAS: GÊNERO, FAMÍLIA} E TRABALHO NO ABC PAULISTA

\section{Resumo}

Neste artigo, discutimos os achados parciais de uma pesquisa sobre trajetórias de homens e mulheres migrantes nordestinos que vieram para o estado de São Paulo (Brasil) nas décadas de i960 e I970. Os resultados revelam diferença significativa na forma de contar suas histórias de vida, que os homens narram a partir de suas experiências no mundo do trabalho e as mulheres a partir dos eventos relativos à esfera privada. Essa diferença nos relatos é aqui interpretada como vinculada não só às identidades de gênero, mas também aos significados atribuídos à família na empreitada conjunta da migração.

ASYMMETRICAL NARRATIVES: GENDER, FAMILY AND LABOUR IN THE ABC REGION (SÃO PAULO STATE, BRAZIL)

\section{Abstract}

This paper analyises some results deriving from research on trajectories of northeastern men and women migrants who came to the state of São Paulo (Brazil) between the I96os and I970s. During interviews we found there to be a significant difference in the speech of men and women in the way that life histories were brought to light. Men usually recite their life histories taking job experiences as reference points, whereas women tell stories about events related to the private sphere. This difference is apprehended here not only as a matter of gender identities, but also with reference to the meanings attributed to the family. 